Momentum: Physics Education Journal, 2 (1), 2018, 1-7

Available at:

http://ejournal.unikama.ac.id/index.php/momentum

Momentum: Physics Education Journal

\title{
Pendekatan Saintifik di Sekolah Dasar
}

\author{
Nurul Ain*, Choirul Huda \\ Program Studi Pendidikan Fisika, Universitas Kanjuruhan Malang, Indonesia \\ *Penulis korespondensi, e-mail: nurulain@unikama.ac.id
}

\begin{abstract}
One of the features of the 2013 Curriculum is a scientific-based learning approach. The purpose of this study was to describe the understanding, implementation, and barriers of elementary school teachers towards a scientific approach. This research method is descriptive qualitative. Respondents were 50 teachers of SDN at Kecamatan Sukun Malang. Data were obtained through open questionnaire techniques and document Teachers' learning plan. The data are described and analyzed to get an overview of elementary school teacher's understanding of the scientific approach. The results show that the scientific approach can serve as a science process skill and a scientific method. Teachers at the SDN in Kecamatan Sukun Malang understand the scientific approach as a science process skill, not yet understanding the scientific approach as a scientific method. These results can be used as a reference to train elementary school teachers in implementing a scientific approach.
\end{abstract}

Keywords: scientific approach; scientific process skill; scientific methods; el ementary school

\begin{abstract}
Abstrak: Salah satu ciri Kurikulum 2013 adalah pembelajaran berbasis pendekatan saintifik. Penelitian ini bertujuan untuk mendeskripsikan pemahaman, pelaksanaan, dan hambatan guru sekolah dasar terhadap pendekatan saintifik. Metode penelitian ini adalah deskriptif kualitatif. Responden sejumlah 50 guru SDN di Kecamatan Sukun Kota Malang. Data diperoleh melalui penyebaran angket terbuka dan dokumen rencana pembelajaran. Data yang diperoleh dideskrpsikan dan dianalisis sehingga didapatkan gambaran umum tentang pemahaman guru Sekolah Dasar terhadap pendekatan saintifik. Hasil penelitian menunjukkan bahwa pendekatan saintifik da pat berfungsi sebagai keterampilan proses sains dan metode ilmiah. Guru-guru Sekolah Dasar di Kecamatan Sukun Kota Malang memahami pendekatan saintifik sebagai keterampilan proses sains, belum memahami pendekatan saintifik sebagai metodeilmiah. Hasil penelitiandapat dijadikan referensi untuk melatih guru sekolah dasar dalam mengimplementasikan pendekatan saintifik.
\end{abstract}

Kata kunci: pendekatan saintifik; keterampilan proses sains; metode ilmiah; sekolah dasar

\section{Pendahuluan}

Indonesia menerapkan Kurikulum 2013 sejak tahun pelajaran 2013/2014 pada jenjang SD hingga SMA/SMK. Salah satu ciri Kurikulum 2013 adalah penggunaan pendekatan saintifik pada proses pembelajaran. Pembelajaran dengan pendekatan saintifik mengharuskan siswa memenemukan pengetahuannya melalui proses mengamati, menanya, mencoba, menalar, dan mengomunikasikan. Langkah-langkah pendekatan saintifik merupakan langkah-langkah dalam memperoleh ilmu, sehingga pendekatan saintifik dapat disebut sebagai pendekatan ilmiah.

Saintifik sebagai suatu pendekatan pembelajaran merupakan pandangan tentang terjadinya suatu proses yang masih bersifat umum. Proses pembelajaran dengan pendekatan saintifik harus diiringi dengan metode yang tepat. Lampiran Permendikbud No 65 tahun 2013 halaman 4, menyatakan bahwa pembelajaran dengan pendekatan saintifik perlu diterapkan dengan pembelajaran berbasis penyingkapan/ penelitian

How to Cite:

Ain, N., \& Huda, C. (2018). Pendekatan Saintifik di Sekolah Dasar. Momentum: Physics Education Journal, 2(1), 1-7. http://dx.doi.org/10.21067/mpej.v1i1.2368 
(discovery/inquiry learning). Berdasarkan Permendikbud tersebut, pendekatan saintifik merupakan dasar dari strategi pembelajaran discovery, inkuiri, dan PBL, artinya pembelajaran dengan pendekatan saintifik menggunakan metode pembelajaran discovery, inkuiri, dan PBL.

Peran guru sangat penting dalam membantu siswa untuk aktif dan berinteraksi dengan lingkungannya. Guru harus dapat membantu siswa agar siswa mampu mengonstruksi pengetahuannya secara mandiri. Hal ini dapat dilakukan melalui metode-metode yang membuat siswa aktif dalam proses belajar mengajar. Metode-metode tersebut juga harus dapat membuat siswa tidak hanya sekadar menghafal, tetapimembuat siswa berfikir dan aktif mencari pengetahuannya.

Metode inkuiri dan discovery merupakan metode yang dapat membuat siswa aktif dalammemperoleh ilmu pengetahuan secara mandiri. Kelebihan metode inkuiri dan discovery dilaporkan dalam beberapa penelitian antara lain adalah Yang, Liao, Ching, \& Chan (2010): dengan pembelajaran discovery induktif,siswa SD memiliki konsep matematika yang lebih baik, Balim (2009): metode discovery dapat meningkatkan prestasi, retensi belajar, dan persepsi terhadap inkuiri, Zerafa \& Gatt (2014): pembelajaran dengan metode inkuiri diterima dengan baik oleh siswa yang mendorong untuk melakukan penelitian dan penyelidikanuntuk menemukan jawaban atas pertanyaan mereka.

Berdasarkan analisis terhadap laporan kegiatan magang II oleh mahasiswa Universitas Kanjuruhan Malang yang magang di SDN Kecamatan Sukun Kota Malang, diperoleh bahwa pendekatan saintifik belum direncanakan kegiatannya pada RPP tersebut. RPP yang terdapat pada laporan mahasiswa adalah RPP yang dilaksanakan di sekolah tersebut. Hal ini berarti bahwa guru belum merencanakan penerapan pendekatan saintifik pada pembelajaran.

Berdasarkan kondisi tersebut, ingin diteliti lebih lanjut bagaimana guru menerapkan pendekatan saintifik di sekolah dasar. Bagaimana pemahaman guru terhadap pendekatan saintifik, dan apa kendalayang dihadapi guru dalam mengimplementasikan pendekatan saintifik pada pembelajaran tematik.

Penelitian ini sangat penting dilakukan, karena: 1) kemampuan guru dalam menerapkan pendekatan saintifik di sekolah dasar menentukan keberhasilan siswa dalam menemukan sendiri ilmu pengetahuannya, 2) Kurikulum 2013 masih dalam proses perbaikan karena masih ditemukannya kekurangan dari segi konseptual dan dari segi teknis. Sumbangan penel itian ini diharapkan dapat menjadi salah satupertimbangan dalam memperbaiki kekurangan implementasi Kurikulum 2013 terutama dari segi metode pembelajaran dengan pendekatan saintifik.

\section{Metode}

Jenis penelitian ini adalah deskriptif kualitatif, yaitu metode yang bertujuan mendeskripsikan atau menggambarkan fenomena-fenomena yang ada. Metode penelitian deskriptif merupakan bagian dari metode penelitian kualitatif. Penelitian kualitatif berlangsung dalam natural setting, berarti penelitian dilakukan sesuai keadaan (kondisi) tempat penelitian. Dengan kata lain dilakukan secara alamiah, apa adanya. Peneliti tidak melakukan manipulasi variabel, tetapi semua kegiatan, keadaan, kejadian suatu variabel berjalan apa adanya. Penelitian deskriptif mencari pemahaman dan penarikan makna dari suatu fenomena yang terjadi.

Penelitian ini dilaksanakan di 10SDN Kecamatan Sukun yang telah menyelenggarakan Kurikulum2013, sebaran data dapat dilihat pada gambar 1. Data dikumpulkan melalui angket terbuka dan dokumentasi berupa RPP yang dibuat oleh guru. Sejumlah 50 guru mengisi angket terbuka. Pengumpulan data dilakukan pada bulan Oktober-November 2017. 




Gambar 1. Sebaran Data Responden

Data yang terkumpul dideskripsikan dan dianali isis untuk mendapatkan informasi tentangpemahaman, pelaksanaan, dan kesulitan guru dalam menerapkan pendekatan saintifik.

\section{Hasil dan Pembahasan}

\subsection{Pemahaman Guru tentang Pendekatan Saintifik}

Pemahaman guru tentang pendekatan saintifik dapat diketahui dari jawaban guru terhadap angket yang telah diisi. Hasil tabulasi data disajikan pada Gambar 2.

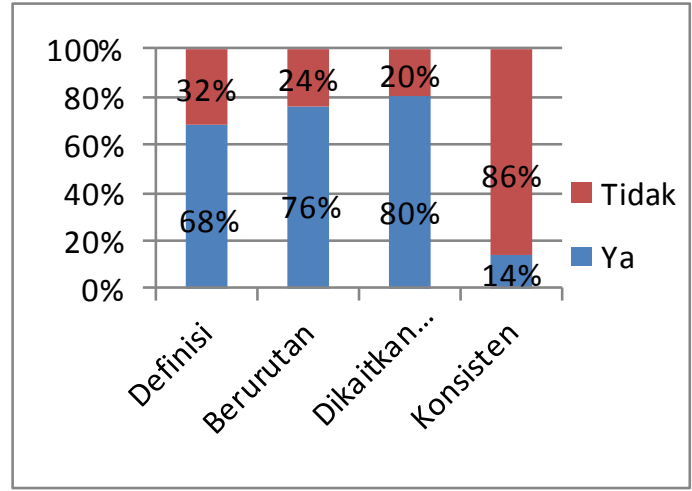

\section{Gambar 2. Hasil Tabulasi Data Angket}

Hasil penelitian dijelaskan sebagai berikut. Sebesar $68 \%$ guru mampu menyebutkan definisi dan langkah-langkah pendekatan saintifik dengan benar. Hal ini berarti bahwa sebesar $32 \%$ guru belum memahami pengertian pendekatan saintifik. Jika pada setiap pembelajaran guru selalu menggunakan pendekatan saintifik, menerapkan setiap tahap atau menerapkan sebagian dari tahap pendekatan saintifik, maka definisi atau tahapan pendekatan saintifik akan terpateri di dalam pemikirannya, sehingga secara otomatis guru akan mampu menyebutkan definisinya atau tahap-tahapnya dengan benar. Kemampuanguru dalam menerapkan pendekatan saintifik akan mampu meningkatkan prestasi siswa (Mahzun (2014), Machin (2014)).

Sebesar $76 \%$ guru menyatakan bahwa pendekatan saintifik harus diajarkan secara berurutan. Hal ini sesuai dengan hasil analisis terhadap RPP yang direncanakan oleh guru yaitu guru dalam mengajarkan pendekatan saintifik tidak secara berurutan dan tidak selalu utuh diajarkan dalam satu kali pertemuan.

Berurutan atau tidak berurutan dalam mengajarkan pendekatan saintifik bergantung pada tujuan pembelajaran. Jika guru ingin melatih keterampilan siswa dalam mengamati, menanya, mencoba, menalar, 
dan mengomunikasikan, maka pendekatan saintifik tidak harus diajarkan secara berurutan. Dalam hal ini fungsi pendekatan saintifik sebagai keterampilan proses sains. Jika fungsi pendekatan saintifik sebagai keterampilan proses sains, maka guru tidak harus mengajarkan langkah-langkah pendekatan saintifiksecara utuh dan berurutan. Guru dapat memilih keterampilan proses yang dikembangkan sesuai dengan materi yang diberikan (Ain, Prabowo, \& Suparman, 2013), mengajarkannya secara bertahap dan berkesi nambungan sehingga pada akhirnya akan terbentuk suatu paduan keterampilan yang lebih utuh guna melakukan penelitian sederhana (Darmodjo \& Kaligis, 1991: 11). Contohnya, guru mengajarkan keterampilanmengamati suatu obyek dengan teliti. Ketelitian dalam mengamati suatu obyek sangat berpengaruh pada hasil pengamatan. Siswa perlu dilatih berulang kali agar memiliki keterampilan mengamati dengan baik. Otak merespons "latihan mental" yang intensif (Wieman and Gilber, 2015: 152). Jika siswa tidak teliti dalam mengamati, maka hasil kegiatan pembelajaran tidak sesuai dengan yang yang diharapkan (Castillo, 2013: 1669). Ada informasi-informasi yang tidak bisa ditangkap atau luput dari perhatian siswa sehingga hasil pembelajaran kurang maksimal. Hal inilah pentingnya mengajarkan keterampilan mengamati dengan teliti kepada siswa. Demikian juga keterampilan-keterampilan lainnya harus dilatihkan secara intensif.

Sebesar $80 \%$ guru berpendapat bahwa pendekatan saintifik harus diajaran melalui metode tertentu. Pendekatan saintifik yang dihubungkan dengan metode pembelajaran tertentu, mempunyai tujuan agar siswa memperoleh pengetahuan melalui serangkaian proses yang sesuai dengan pendekatan saintifik. Metode pembelajaran yang sesuai atau sejalan dengan pendekatan saintifik adal ah discovery/inkuiri learning, dan project based learning (Permendikbud No 65: 3), dan PBL (problem based learning). Langkah langkah pada pembelajaran PBL, inkuiri, dan discovery sesuai dengan langkah-langkah pendekatan saintifik. Metode-metode tersebut harus diajarkan secara berurutan. Pemberian metode tersebut memfungsikan siswa sebagai seorang "ilmuwan cilik". Siswa diajarkan bagaimana cara ilmuwan menemukan pengetahuan, yaitu melalui serangkaian proses yang disebut metode ilmiah. Metode ilmiah adalah keterampilanyangharus dimiliki agar menjadi peneliti yang sukses (Karsai \& Kempis, 2010: 634). Pembelajaran melalui metode metode yang sesuai dengan pendekatan saintifik sangat penting diajarkan kepada siswa, sehingga siswa terbiasa "menemukan" konsep atau pengetahuan secara sistematis. Metode pembelajaran yang sejalan dengan pendekatan saintifik dapat meningkatkan pemahaman siswa (Argaw, dkk (2017), Abdi (2014)), meningkatkan kemampuan berpikir kritis (Nafiah dan Suyanto, 2014), dan meningkatkan kemampuan berpikir kreatif (Nicholes dan Stephens, 2013). Pengalaman ini akan terus dibawa hingga dewasa, menjadi ilmuwan yang sesungguhnya.

Hasil analisis terhadap RPP menunjukkan bahwa guru menggunakan pendekatan saintifik dengan model PBL, inkuiri, discovery, jigsaw, kooperatif, dan lain-lain. Namun, pada langkah-langkah pembelajaran, guru tidak menjabarkan langkah-langkah yang sesuai dengan model pembelajaran yang dipilih, tetapi tetap mencantumkan langkah mengamati, menanya, menalar, menyimpulkan dan mengomuni kasikan. Hal ini berarti bahwa guru belum memahami pendekatan saintifik sebagai metode ilmiah.

Sebesar $14 \%$ guru konsisten dalam menjawab keseluruhan pertanyaan, sedangkan sebesar $86 \%$ tidak konsisten. Konsistensi jawaban guru terhadap semua pertanyaan artinya adalah tidak ada pertentangan antara penyataan satu dengan pernyataan lainnya. Konsistensi jawaban guru ini menunjukkan pemahaman guru terhadap pendekatan saintifik. Hal ini berarti bahwa hanya $14 \%$ guru yang betul-betul memahami pendekatan saintifik.

\subsection{Implementasi Pembelajaran dengan Pendekatan Saintifik di SD}

Tabulasi data terhadap angket yang meminta guru menjelaskan pengalamannya mengajarkan pendekatan saintifik disajikan pada Gambar 3. 


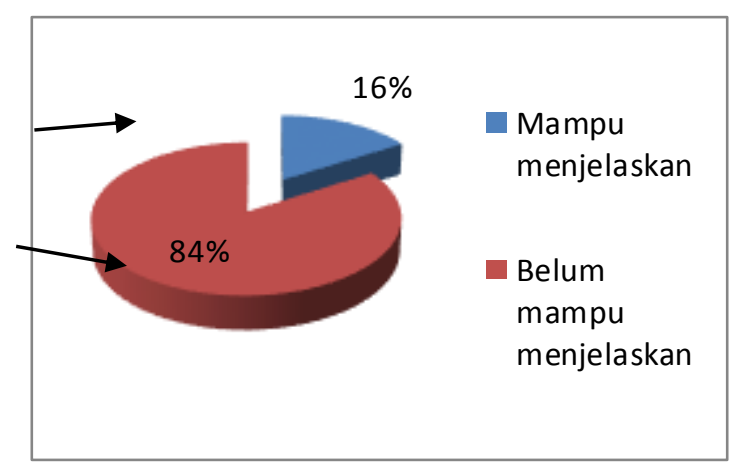

Gambar 3. Kemampuan guru menjelaskan pengalamannya meng-ajar dengan pendekatan saintifik

Gambar 3 dapat dijelaskan sebagai berikut. Guru yang mampu menjelaskan pelaksanaanpe mbelajaran yang sesuai dengan pendekatan saintifik dengan benar sebesar $16 \%$, sedangkan sebesar $84 \%$ belum mampu menceritakan pelaksanaan pembelajaran dengan pendekatan saintifik secara lengkap. Kondisi tersebut menyiratkan bahwa hanya sekitar $16 \%$ guru mempunyai pengalaman mengajarkan pembelajaran pendekatan saintifik dengan baik. Guru yang sudah berpengalaman dalam mengajarkan pendekatansaintifik akan mudah menceritakan pengalamannya (Ayuni, 2015: 6), sebaliknya guru yang belum mempunyai pengalaman dalam membelajarkan pendekatan saintifik akan sulit menceritakan pengalamannya dalam membelajarkan pendekatan saintifik.

\subsection{Kesulitan Guru dalam Melaksanakan Pendekatan Saintifik}

Kesulitan guru dalam membelajaran pendekatan saintifik dianal isis dari angket terbukayangdiberikan kepada guru dan menganalisis RPP yang dibuat oleh guru. Berdasarkan hasil analisis tersebut diperoleh bahwa kesulitan guru dalam melaksanakan pendekatan saintifik adalah belum pahamnya guru terhadap pendekatan saintifik. Guru memahami pendekatan saintifik seperti yang tersurat bukan yang tersirat. Halini terjadi karena guru hanya berpedoman pada buku yang belum benar dalam menerapkan pendekatansaintifik (Rumiati \& Andajani, 2016), dan belum memahami komponen metode ilmiah (McPherson, 2001: 242).

Kurang pahamnya guru terhadap pendekatan saintifik dapat dilihat dari pe rencanaan pembelajaran dengan pendekatan saintik dan menggunakan metode inkuiri, discovery, dan PBL. Contohnya padaRPPyang menggunakan pendekatan saintifik dengan metode inkuri. Pada langkah pembelajaran guru tetap menuliskan langkah-langkah pendekatan saintifik seperti mengamati, menanya, mencoba, menalar dan mengomunikasikan. Guru yang memahami pembelajaran dengan pendekatan saintifik dan menggunakan metode inkuiri akan menuliskan langkah-langkah pembelajaran sesuai dengan langkah-langkah metode inkuiri, yaitu merumuskan masalah, membuat hipotesis, mengumpulkan data, menganalisis data, dan membuat kesimpulan.

Guru yang memahami pendekatan saintifik dengan metode inkuiri akan dapat mengaitkan langkah mengamati dengan langkah merumuskan masalah, mengaitkan langkah menanya dengan mengajukan hipotesis, mengaitkan mencoba dengan mengumpulkan data, mengaitkan menalar dengan menganalisis data, dan mengaitkan langkah mengomunikasikan dengan langkah menyimpulkan.

Pembelajaran berbasis pendekatan saintifik dengan metode inkuiri dapat dilakukan dengan sebagai berikut. Pengamatan terhadap suatu obyek akan timbul permasalahan yang akan dinyatakan dalamrumusan masalah. Berdasarkan rumusan masalah yang telah diajukan, guru mendorong siswa untuk menanya dan 
memberi penjelasan tentang fenomena yang diamati atau menanyakan latar belakang hipotesis. Kegiatan berikutnya adalah mencoba atau merancang suatu eksperimen dalam rangka mengumpulkan data. Data yang diperoleh kemudian dianalisis melalui penalaran yang logis sehingg a diperoleh kesimpulan yang akan dikomunikasikan kepada siswa lain.

\section{Simpulan}

Implementasi pendekatan saintifik dalam pembelajaran dapat berfungsi sebagai keterampilan proses sains dan metode ilmiah. Fungsi pendekatan saintifik sebagai keterampilan proses sains dalampembelajaran dapat diajarkan secara terpisah dengan tujuan melatih siswa agar terampil dalam memperoleh sains. Fungsi pendekatan saintifik sebagai metode ilmiah dalam pembelajaran harus dikaitkan den gan metode-metode yang sejalan dengan pendekatan saintifik, dengan tujuan melatih siswa dalam menemukan pengetahuannya melalui serangkaian proses yang disebut metode ilmiah.

Guru-guru SDN di Kecamatan Sukun Kota Malang memahami pendekatan saintifik yang be rfungsi sebagai keterampilan proses, dan belum memahami pendekatan saintifik sebagai suatu metodeilmiah. Hasil penelitian dapat dijadikan referensi untuk melatih guru sekolah dasar dalam menerapkan pendekatan saintifik yang berfungsi sebagai keterampilan proses sains dan metode ilmiah, dan juga dapat digunakan sebagai dasar untuk mengembangkan pembelajaran berbasis pendekatan saintifik guna perbaikan implementasi Kurikulum 2013.

\section{Ucapan Terima Kasih}

Ucapan terima kasih disampaikan kepada Rektor Universitas Kanjuruhan Malang yang telah memberikan dana penelitian dan guru-guru SDN Kecamatan Sukun Malang yang telah bersedia menjadi responden.

\section{Daftar Rujukan}

Abdi, A. 2014. The Effect of Inquiry-based Learning Method on Students' Academic Achievement in Science Course. Universal Journal of Educational Research 2(1): 37-41. DOI: 10.13189/ujer.2014.020104

Ain, N., Prabowo, \& Suparman, K. 2014. Guru kreatif kelas IV SD, tema "Selalu Berhemat Energi": Implementasi Kurikulum 2013. Prosiding Seminar Nasional Pendidikan Sains PPS Unesa 18 Januari 2014. Hal. 29-38. Surabaya: Jaudar Press. ISBN 978-602-14702-6-8.

Argaw, A. S., Haile, B. B., Ayalew, B.T., and Kuma, S. G. 2017. The Effect of Problem Based Learning (PBL) Instruction on Students' Motivation and Problem Solving Skills of Physics. EURASIA Journal of Mathematics Science and Technology Education, 13(3):857-871. http: doi.org/10.12973/eurasia.2017.00647a.

Ayuni, F. N. 2015. Pemahaman guru terhadap pendekatan saintifik (scientific approach) dalam pembelajaran geografi. Gea, Jurnal Pendidikan Geografi, 15(2): 1-7.

Balim, A.G. (2009). The effects of discovery learning on students' success and inquiry learning skills. Eurasian Journal of Education Research. 35, 1-20.

Castillo, M. 2013. The Scientific Method: A Need for Something Better? AJNR Am J Neuroradiol 34:1669 1671. http://dx.doi.org/10.3174/ajnr.A3401

Darmojo, H dan Kaligis, J.R.E. 1992. Pendidikan IPA 2. Jakarta: Depdikbud Dirjendikti.

Karsai, I and Kempis, G. 2010. The Crossroads between Biology and Mathematics: The Scientific Method as the Basics of Scientific Literacy. BioScience. 60(8): 632-638.

Machin, A. 2014. Implementasi pendekatan saintifik, penanaman karakter dan konservasi padapembelajaran materi pertumbuhan. Jurnal Pendidikan IPA Indonesia. 3(1): 28-35.

Mahzum. 2014. Aplikasi pendekatan pembelajaran saintifik metode inquiry based learning padakompetensi dasar menerapkan hukum-hukum yang berhubungan dengan fluisa status dan dinamis untuk meningkatkan hasil belajar siswa kelas X SMK. Jurnal Phenomenon. 4(1): 111-127. 
McPherson, G.R. 2001. Teaching \& Learning the Scientific Method. The American Biology Teacher, 63(4): 242-245.

Nafisah, Y.N dan Suyanto, W. 2014. Penerapan model pembelajaran problem-based learning, untuk meningkatkan keterampilan berpikir kritis dan prestasi belajar siswa. Jurnal Pendidikan Vokasi, 4(1): 125-143.

Nichols, A. J. and Stephens, A. 2013. The Scientific Method and the Creative Process: Implications for the K6 Classroom. Journal for Learning through the Arts, 9(1):1-12.

Permendikbud No 57 tahun 2014 tentang Kurikulum 2013 Sekolah Dasar dan Menengah.

Ruminiati dan Andayani, K. 2016. Analisis kesesuaian isi buku tematik kelas IV sekolah dasar dengan penddikan karakter dan pendekatan saintifik. Sekolah Dasar, 25(1): 27-36.

Yang, E.F.Y., Liao, C.C. Y., Ching, E., Chang, T., \& Chan, T. W. (2010). The effectiveness of inductive discovery learning in 1: 1 mathematics classroom. Proceedings of the 18th International Conference on Computers in Education. Putrajaya, Malaysia: Asia-Pacific Society for Computers in Education. 743747.

Zerafa, I., \& Gatt, S. (2014). Implementing a science curriculum reflecting an inquiry based approach in the Upper Primary Years. IPSE Journal, 1(2), 13-26.

Wieman, C. and Gilbert. S. 2015. Taking a Scientific Approach to Science Education, Part I-Research. Microbe, 10 (4), 152-156 